UDC 94:374.3

DOI https://doi.org/10.32838/2663-5984/2021/2.16

Kalachova I.I.

Belarusian State University

\title{
TRADITIONS OF EDUCATION CHILDREN IN BELARUSIAN NOBLE FAMILIES IN THE 19TH - EARLY 20TH CENTURIES
}

The article is devoted to the problem of organizing the education and upbringing of children and adolescents from the upper strata of Belarusian society during the period when the territory of Belarus was part of the Russian Empire. The goal of the article is to study the conditions, ideological prerequisites and basic forms of child rearing in Belarusian noble families in the second half of the 19 th - early 20th centuries. The article shows the living conditions of young Belarusian noblemen, which significantly influenced their cognitive processes, determined the circle of people with whom young people interacted during education, determined their change in accordance with the stages of growing up of the child. The text of the article provides information about the ways of organizing the educational process, its subjects, ideological, political, cultural and social determinants. Recollections of eyewitnesses of that era about their personal experience of education and upbringing in childhood are given. The traditions of teaching and raising children are shown through the prism of the history of childhood as a section of family history and the history of everyday life, which had typical features in different social groups of the Belarusian society of the 19th century. An important place in this study is given to the conditions of the pedagogical process, which often began on the territory of a rural noble estate and continued either in public schools or gymnasiums for boys, or in specialized educational boarding schools for girls. The author's attention in this article is focused on the history of education and upbringing in the period from the birth of a child to the age of adolescence, when he often completed the period of home education and left his parents' home to continue his education outside of it. This comprehensive and interdisciplinary study of the history of education and upbringing of young nobles combines features of history, ethnography, sociology, socio-cultural anthropology, etc.

Key words: history of education, home education, children, noble family, enlightenment.

Problem statement. The 19th century is very controversial for the history of education in Belarus. On the one hand, the 19th century is a period of significant growth of literature and arts in the Belarusian lands, which would have been impossible without a high level of education of the upper strata of society. But on the other hand, after the occupation of the eastern lands of the former Polish-Lithuanian Commonwealth by the Russian Empire and a number of national liberation uprisings against it in the late 18th and mid 19th centuries, there was a clear regression of the higher education system. The Russian authorities closed the Vilnius University and the Polotsk Academy under the pretext of fighting separatist sentiments in them. The state system of Russian schools and gymnasiums, which replaced the religious colleges of the 17th and 18 th centuries, was under the strict control of the Russian authorities. This could not suit the Belarusian nobility, which for the most part was skeptical of the Russian Empire. But they had no choice...

The goal of the article is to study the conditions, ideological prerequisites and basic forms of child rearing in Belarusian noble families in the second half of the 19 th - early 20 th centuries.

Analysis of recent research and publications. The most significant in the field of the history of education, the life of the nobles and the culture of the privileged class in Belarus, the history of family relations and the social status of children are monographic studies and individual publications of such modern Belarusian authors as S. Shydlouski, L. Rakava, I. Kalachova, A. Shavialiova, U. Ganski, etc. Very informative in the study of this problem the publication of contemporaries of the events in question, memoirs and other works of E.T. Massalski, L. Potocki, Ł. Gołębiowski, F. Karpiński, I.E. Lachnicki, G. Puzynina, etc. However, despite the existence of separate publications in this area, important issues remain virtually unexplored, which determines the high degree of relevance of this study.

Presentation of the main research material. In the Belarusian historical science, the traditions of raising children in families of the privileged class in the 19th century were first studied by L. Rakava [3]. Her 
article uses a number of author's theoretical and methodological approaches, in particular, in determining the ethno-cultural belonging of the nobility and identifying the pedagogical traditions of the privileged class as part of the ethnic tradition of Belarusians.

This period was characterized by strong external influences on the development of the culture of the privileged class of Belarus, primarily Russian and Polish cultures, and through their mediation - West European cultures (French, German, English), which explains the need to study the external cultural context in which the Belarusian pedagogical tradition was formed.

Education in aristocratic families was often of a project nature and focused on a certain ideal. The pedagogical ideal could be clearly articulated, for example, in the instructions for the upbringing of children (primarily direct heirs), which were usually compiled by parents and addressed to tutors, teachers and the children themselves. Most of the strategies of family education in the noble environment remained within the Christian tradition. Accordingly, the person of Christ was considered as the standard of universal human virtues. Examples from the lives of ancestors (or patrons of the family), historical and biblical heroes, and to a lesser extent literary characters were popular. Usually, the pattern for inheritance was laid at the level of the name that was given to the child in honor of a famous ancestor, an outstanding historical figure or a saint. An idea of the list of historical, literary and mythological heroes, on the example of which the natives of Belarus, in particular, the carriers of the Polish-speaking Catholic noble tradition, were brought up, is given by the book of Jan Barszczewski "The Gentleman Zavalnia or Belarus in Fantastic Stories". Thus, its pages are dominated by names associated with ancient history (Alexander the Great, Homer, Virgil, King Leonidas of Sparta, Cicero, Horace, Gaius Julius Caesar, etc.) and Christian tradition (Jesus, the Virgin Mary, St. Peter, Adam, Eve, etc.) [6].

For the nobility estates were the personification of a small homeland. They were an environment in which family traditions and history accumulated. The estate influenced the formation of the class-clan identity. The tasks of class education of the younger generation were solved within the estate by various means. Portrait galleries of ancestors were collected, places of their burial were memorialized, "Silva rerum" - handwritten books with stories from family history were kept, the names of the members of the family were assigned to villages. Memorial plaques were erected to commemorate the historical events associated with the area. The pediments of the porticos and gates of the noble residences were decorated with the coats of arms of the owners of the estate. The coat of arms of the family could also be located above the fireplace, on the stove tiles, above the entrance to the porch. Allegorical drawings, inscriptions in Polish and Latin, life credo and symbol of faith, mottos were found on the gates, over the door, etc. To honor the history of the family, a park served, where chapels-tombs, monuments, obelisks, stones with epitaphs, memorial trees were installed. The temples founded by the representatives of the clan became the family pride. Historical documents, books, and art objects are collected. By such means, an educational environment was formed, in which the young generation acquired the first knowledge about their locality and about their kind [5, p. 69].

Depending on the property status and pedigree, the ideal of upbringing among parents could differ significantly. For the aristocracy, public activity was a priority. Boys in such families were prepared for a political or military career, so that they would become model citizens of the Fatherland and outstanding representatives of the family; girls-for the role of housewives of the "open house", which was supposed to live in public and intellectual-artistic interests. At the same time, a significant part of the families of medium and small nobles oriented their children to practical economic activities on the estate. However, these stereotypes have changed over time. According to comte L. Potocki, since the last quarter of the 18th century in the aristocratic environment, it was no longer considered unconditionally mandatory to raise boys "for God and people, the sword and the council". The ideal of public service was replaced, along with the fashion for French culture, by sybaritic sentiments. Increasingly, school education was replaced by home schooling for the children of the Belarusian nobility. The knowledge gained from foreign tutors, whose presence in the noble family became an element of prestige, began to be appreciated [2, p. 108-109; 12, p. 12].

The pedagogical ideal was also influenced by the political and philosophical beliefs of the parents. In conservative ("Sarmatian") families, children were brought up in religion, taught to honor their parents, modesty and courtesy in their behavior with their elders, and taught to accept the social hierarchy. An illustration of this type of education can serve as a memoir of F. Karpinski. So, according to his recollections, he did not dare to sit in front of his father, not only without permission, but even to stand leaning on the wall $[10$, s. 4,16$]$. 
Aristocratic education in the spirit of Enlightenment included the ideals of self-discipline and rationality, as well as order, rationality, and consistency in actions, which could, for example, be realized through the introduction of a daily schedule for children. In such a system of views, the idea of the benefits of creating ascetic conditions for children was popular. Children, for example, could be taught to limit themselves in means, determining for them a small monetary allowance, which did not provide for luxury or high comfort. The extreme manifestation of such views was the tradition of "dziadzkavannie", when the children of rich landowners were given to be raised in peasant families for several years at the age of 7-10 years, described in detail in the novel by the Belarusian romantic writer Uladzimir Karatkievich "The rye under thy sickle" [14, p. 82-83].

The ideal of upbringing could differ not only in different social strata, but also within the same family. The most obvious thing is the presence of different ideals in the upbringing of girls and boys. They also differed with respect to older children (future heirs to lands and titles) and younger children. However, it is possible to identify the components of education that were universal: the nobles wanted to see their children religious, obedient to their elders, sociable and healthy (boys - strong). Education in noble families was based on family and class values, which provided for the actualization of historical memory. The noble children got acquainted with the history of Belarus first of all thanks to the references to the participation of their ancestors in historical events. A significant aspect of home education in the families of the vast majority of Belarusian nobles was the preservation of Western cultural identity. Accordingly, an important educational element was the actualization of a complex of traditions, customs, and norms that were identified with the national canon and the "golden era" of the former Polish-Lithuanian Commonwealth [5].

The ideal of education also corresponded to the ideal of the educator: parents showed firmness and consistency in the upbringing of their children, but they did it with love and intelligence. Pedagogical practices in the noble estate extended not only to the children of the owners. The traditional family model provided that the husband would perform certain pedagogical duties in relation to his wife. A woman was expected to obey, and a man was expected to take care of his wife financially, intellectually, and spiritually. Together, they performed a pedagogical function in relation to the small nobles who were financially dependent on them and the peasants who were legally dependent on them. Among the middle and small gentry, wealthy and well-born noble families were considered as role models. Thus, the owners of rich estates were not only an example for their own children, but also fulfilled a broader patriarchal mission in their social environment [2, p. 46].

In turn, representatives of a wide range of members of the family, primarily the closest relatives, godparents, took part in the upbringing of the younger members of the noble family. Significant was the educational influence of the priests, as well as representatives of the hired staff (nurses, nannies, tutors, teachers), who directly cared for the noble children and were engaged in their education. All of the above groups formed the socializing environment of the noble estate, where the child's personality was formed. Count L. Potocki, describing the impression of his childhood and youth, fondly recalls not only his parents, but also representatives of the closest socially heterogeneous environment in which he grew up: the estate manager, the housekeeper, the priest, the Bernardine monk, the teacher, the neighbors, the cook, the coachman, the footman [2, p.18].

In the families of the Belarusian nobles, home education remained a common phenomenon. In wealthy families, children were taught from the age of three, sometimes even earlier. First of all, they taught foreign languages (most often Latin, French, German) and arithmetic. This was done by foreign bons (usually French or German), who, in addition to teaching (learning to read, write, and dance), performed the same duties as ordinary nannies. Parents could also teach children to read and write. Children were able to read and perform elementary arithmetic operations at the age of $4-5$ years $[1$, p. $128 ; 8$, p. 91].

Usually children were taught at home until the age of 7-8, and then sent to parochial schools, girls to closed boarding schools - private or at monasteries. However, in wealthy families, children could receive a course of primary school and prepare for admission to the gymnasium and at home. In this case, a class system of education was introduced from the age of $7-8$ [8, s. 88, 90]. This stage of training could last 3-4 years, and the educational process was provided by tutor or governess. In such cases, children left their parents' home at the age of 10-12 [9, s. 292].

For boys home education usually served as a preparatory stage for entering school. For girls in the late 18th and first half of the 19th centuries, home education often remained the only form of education. For example, according to I.E. Lachnicki, in 1816 in the parochial schools of the Grodno province, there were only 79 female students for 465 male students. The Academic Gymnasium in Svislach at Vilnius Uni- 
versity had 278 male students and only 3 female students. Since the last quarter of the 19th century, more and more girls begin to study in boarding schools and gymnasiums. From this time on, home schooling is only a preparatory stage for them to acquire more thorough knowledge [11, s. 74-76].

Conclusions. Thus, during the 19th - early 20th centuries, with the popularization of the ideas of Enlightenment, and later Positivism and the formation of the national liberation movement, education and upbringing began to be perceived in the Belarusian noble environment as an important public institution. In the presence of such a consensus, a wide variety of pedagogical methods and strategies were simultaneously observed, which could come into conflict with each other even within the same family. In the general educational process at that time, elements of scientific concepts, religious requirements, old noble patterns of behavior and traditional methods of ethnopedagogy coexisted [13, p. 8-9]. In many nobles families, usually low-income, the principle of innate qualities, traditional for the conservative (old noble) worldview, was cultivated. In the intellectual circles that actively formed public opinion, such a position was considered marginal. In the Belarusian noble environment during this period, the ideal took root, according to which the goal of family education and home education was to ensure the harmonious (intellectual, aesthetic, moral and physical) development of the child's personality. It was considered as a necessary prerequisite for the future successful self-realization of noble children as carriers of an elite socio-cultural mission. An important role in this strategy was given to home education. Among its most significant tasks was the preparation for admission to public schools or gymnasiums, as well as a deeper development of foreign languages and disciplines of the aesthetic cycle than was provided by the school curriculum. A feature of family education and home education in the conditions of a noble estate was the participation in the educational process of a wide range of people belonging to different social groups. The transfer of knowledge, values and norms was two-sided, which caused, for example, a certain possibility of the influence of elements of the ethnopedagogical tradition on the upbringing of the children of nobles. In turn, the landowners performed pedagogical functions in relation to both their own children and the entire population of the estate, which was due to the very nature of patriarchal relations. Therefore, we can talk about the presence of a specific educational and socializing environment of the noble manor, in which the process of reproduction took place not only of the culture of the noble class, but also of its social environment from other classes.

\section{References:}

1. Масальскі Э.Т. 3 успамінаў (1799-1824). Маладосиьь. 2014. № 6. С. 127-138.

2. Патоцкі Л. Успаміны пра Тышкевічаву Свіслач, Дзярэчын і Ружану. Мінск : Полымя, 1997. 270 с.

3. Ракава Л.В. Эвалюцыя традыцый сямейнага выхавання беларусаў у XIX - XX ст. Мінск : Беларуская навука, 2009. $311 \mathrm{c.}$

4. Калачова І.І. Народныя традыцыі і звычаі выхавання: этнапедагагічная спадчына народаў Беларусі. Мінск : Нацыянальны інстытут адукацыі Рэспублікі Беларусь, 1999. 179 с.

5. Шыдлоўскі С.А. Культура прывілеяванага саслоўя Беларусі: 1795-1864 гг. Мінск : Беларуская навука, 2011. 168 c.

6. Шыдлоўскі С.А. Уласныя імёны ў кнізе Я. Баршчэўскага «Шляхціц Завальня» як крыніца рэканструкцы этнічнай карціны свету прывілеяванага саслоўя беларускага Падзвіння ў першай палове XIX ст. Беларускае Падзвінне: вопыт, методыка і вынікі палявых даследаванняў / пад рэд. Д.У. Дука. Наваполацк : ПДУ, 2009. С. 287-290.

7. Калачова I.І. Ад добрага кораня - добры парастак: этнапедагагічныя традыцыі беларусаў у выхаванні дзяцей. Мінск : НМЦэнтр, 1999. 124 с.

8. Felińska E. Pamiętniki z życia Ewy Felińskiéj. Seria I: w 3 t. Wilno: Nakładem i drukiem J. Zawadzkiego, 1856. T. $1.467 \mathrm{~s}$.

9. Gołębiowski Ł. Domy i dwory. Warszawa: Druk. N. Gkücksberga, 1830. 296 s.

10. Karpiński F. Pamiętniki. Poznań: W. Simon, 1884. 178 s.

11. Lachnicki I.E. Statystyka Gubernii Litwesko-Grodzienskiey. Wilno: Nakład i druk J. Zawadzki, 1817. 88 s.

12. Puzynina G. W Wilnie i w dworach litewskich. Pamiętnik z lat 1815-1843. Wilno: Druk J. Zawadzkiego, 1928. $389 \mathrm{~s}$.

13. Калачова I.I. Мужчынскае і жаночае ў традыцыйнай культуры беларусаў. Мінск : Беларуская навука, 2019. $166 \mathrm{c}$.

14. Shavialiova A., Ganski U. The history of everyday life in system of historical research. European and national dimension in research / ed. by D. Lazovski. Novopolotsk: PSU, 2012. Part 1. P. 81-84. 
КаЛачова І.І. ТРАДИЦІї ВИХОВАННЯ ДІТЕЙ У БІЛОРУСЬКИХ ШЛЯХЕТСЬКИХ СІМ'ЯХ У ХIX - НА ПОЧАТКУ ХХ СТ.

Статтю присвячено проблемі організації навчання $і$ виховання дітей і підлітків із вищих верств білоруського суспільства в період перебування території Білорусі у складі Російської імперії. Метою статті є вивчення умов, ідейних передумов і основних форм виховання дітей у заможних білоруських шляхетських сім'ях у другій половині XIX - початку XX cm. У статті показано умови життя молодих білоруських шляхтичів, які значною мірою впливали на їхні пізнавальні прочеси, визначено коло осіб, з якими взаємодіяли молоді люди під час навчання, показано зміну ции осіб згідно з етапами дорослішання дитини. Текст статті наводить відомості про способи організації навчального процессу, його суб' єктів, ідейні, політичні, культурні і соџіальні детермінанти. Наведено спогади очевидиів тієї епохи про їхній особистий досвід навчання і виховання в дитинстві. Традиџї навчання і виховання дітей показуються через призму історії дитинства як розділу сімейної історії та історії повсякденності, яка мала істотні особливості в різних соичільних верствах білоруського суспільства ХIX сm. Важливе місие у иъому дослідженні відведено умовам педагогічного процесу, який часто починався на території сільського шляхетського маєтку і тривав або в публічних школах чи гімназіях для хлопчиків, або у спеціалізованих освітніх пансіонах для дівчат. Увагу автора в рамках статті зосереджено на історії навчання і виховання в період із народження дитини і до досягнення нею підліткового віку, коли вона, як правило, завершувала період домашньої освіти $і$ залишала дім батьків для продовження освіти за його межами. Це комплексне і міждисциплінарне дослідження історії навчання і виховання молодих заможних иляхтичів поєднує у собі риси історії, етнографії, соиіологї̈, соиіально-культурної антропології та ін.

Ключові слова: історія освіти, домашня освіта, діти, иляхетська родина, просвітництво. 